\title{
Wisata Perikanan Edukatif Dengan Pendekatan Arsitektur Ekologis Di TANJung Priok
}

\author{
Kusumo Hastuti, Musyawaroh, Tri Joko Daryanto \\ Program Studi Arsitektur \\ Jurusan Arsitektur Fakultas Teknik \\ Universitas Sebelas Maret Surakarta \\ Email: tututantitu@gmail.com
}

\begin{abstract}
The background that make educational fishery tourism in Tanjung kodok feasible to be developed is the opportunity to improve tourism potency in Tanjung Kodok, Lamongan Regency, to raise effectiveness of fishery which is basic potential in Lamongan, and to provide educational recreation for tourists of all ages in Tanjung Kodok. Its problem solving has been formulated by designing resort in Tanjung Kodok, Lamongan regency, with Ecological Architecture based on plan and design concept.The aim that can be attained of the research is making a green resort generally for Indonesian people and especially for East Java People in order to enjoy educational fishery tourism in Tanjung Kodok without putting aside its Ecological Architecture approach. Method used to solve the threat of environmental damage is applying Ecological Architecture on its plan and design.The design concept related to Ecological Architecture approach includes building orientation facing the north and south, vertical garden installment as a sunscreen for an open side facing besides north and south, the application of fountain as natural cooler in the site, the use of trees as natural shade on public area, mangrove plantation for shore conserving, the utilizing of raindrop reservoir located on the site, and the application of plants roof on every building.
\end{abstract}

Keywords: Educational Fishery Tourism, Ecology Architecture, Plants Roof, Vertical Garden

\section{PENDAHULUAN}

Dewasa ini jaman semakin berkembang, kebutuhan manusia juga mengalami perkembangan. Hiburan menjadi salah satu kebutuhan manusia seiring dengan berkembangnya jaman tersebut.

Sehubungan dengan kebutuhan manusia akan hiburan tersebut, banyak lokasi di Indonesia yang sedang dikembangkan menjadi kawasan pariwisata seperti kawasan Tanjung Kodok di Kabupaten Lamongan, Jawa Timur. Selain potensi pariwisata, kawasan Tanjung Kodok ini juga memiliki potensi utama yaitu perikanan. Berdasarkan pada kedua potensi tersebut maka potensi pariwisata dan perikanan dapat disinergikan sehingga dapat menjadi sebuah tempat wisata baru di Tanjung Kodok.

Sajian rekreasi yang edukatif dirasa perlu dihadirkan bagi wisatawan Tanjung Kodok yang mayoritas berusia sekolah. Dewasa ini semakin banyak dan bermacam
- macam tempat wisata yang dihadirkan di Indonesia guna memenuhi kebutuhan hiburan bagi masyarakat. Tetapi seiring dengan semakin banyaknya tempat wisata, konsep yang dihadirkap sering kali hanya memenuhi kebutuhan rekreasi. Padahal apabila dilihat kebutuhan hiburan/ wisata sekarang ini bukan hanya milik usia dewasa saja, melainkan para usia pelajar justru sering mengunjungi beberapa tempat wisata untuk berlibur. Hal ini seperti yang ditunjukkan Khosyatillah (2009:40-41) yang menyebutkan bahwa pelajar/ mahasiswa memiliki persentase terbanyak sebagai pengunjung WBL yaitu sebanyak $23 \%$. Oleh karena itu dirasa sajian rekreasi yang edukatif perlu disajikan untuk para pengunjung pelajar yang mendominasi kunjungan tempat wisata di Tanjung Kodok ini.

Strategi desain dibutuhkan untuk mengatasi ancaman kerusakan lingkungan yaitu dengan menggunakan pendekatan Arsitektur Ekologis. Pemenuhan kebutuhan manusia di bidang papan (pembangunan) 
yang dilakukan terus menerus dikhawatirkan akan menjadi ancaman kerusakan lingkungan bahkan pencemaran alam. Melihat fenomena bahwa saat telah dirancang tempat wisata ikan ini akan menimbulkan sebuah ancaman terhadap pencemaran lingkungan atau pun adanya kerusakan kelestarian alam, oleh karena itu Arsitektur Ekologis digunakan untuk menjadi strategi desain dalam penanggulangan ancaman tersebut. Hal ini seperti yang disampaikan Frick (1998) bahwa Arsitektur Ekologis menghasilkan keselarasan antara manusia, lingkungan alam, sosial - budaya, ruang, serta teknik bangunan. Pendekatan Arsitektur Ekologis dalam perancangan tempat wisata ikan ini diharapkan akan meminimalkan potensi ancaman mengenai pencemaran lingkungan tersebut dan dapat menjaga keseimbangan alam.

\section{METODE}

Konsep perencanaan dan perancangan membutuhkan metode dalam pembuatannya. Metode pembahasan yang digunakan adalah sebagai berikut:

A. Identifikasi Permasalahan

Tahap identifikasi permasalahan merupakan tahapan untuk mengidentifikasi fenomena yang terkait dengan kebutuhan dalam perencanaan wisata perikanan edukatif.

B. Pengumpulan Data dan Informasi

1. Kebutuhan data

Tahapan pengumpulan data dan informasi dapat dilakukan setelah mengetahui macam dan jenis data yang dibutuhkan. Data yang dibutuhkan antara lain:

Tabel 1. Daftar Data Wisata Perikanan yang Dibutuhkan

\begin{tabular}{|l|l|}
\hline $\begin{array}{l}\text { Data yang } \\
\text { Dibutuhkan }\end{array}$ & Macam Data \\
\hline & $\begin{array}{l}\text { 1. Sarana dan } \\
\text { Prasarana } \\
\text { Kepariwisataan }\end{array}$ \\
\cline { 2 - 2 } $\begin{array}{l}\text { Wisata } \\
\text { Edukatif }\end{array}$ & $\begin{array}{l}\text { 2. Persyaratan } \\
\text { Wisata Perikanan } \\
\text { a. Area operasi } \\
\text { b. Kualitas air }\end{array}$ \\
\hline
\end{tabular}

\begin{tabular}{|l|l|}
\hline & $\begin{array}{l}\text { c. Sistem Air } \\
\text { d. Akuarium }\end{array}$ \\
\hline
\end{tabular}

Tabel 2. Daftar Data Teori yang

Dibutuhkan

\begin{tabular}{|c|c|}
\hline $\begin{array}{l}\text { Data yang } \\
\text { Dibutuhkan }\end{array}$ & Macam Data \\
\hline $\begin{array}{l}\text { Tinjauan Teori } \\
\text { Konsep } \\
\text { Edukatif }\end{array}$ & $\begin{array}{l}\text { Metode } \\
\text { Penerapan } \\
\text { Konsep Edukatif }\end{array}$ \\
\hline \multirow{3}{*}{$\begin{array}{l}\text { Tinjauan Teori } \\
\text { Arsitektur } \\
\text { Ekologis }\end{array}$} & $\begin{array}{l}\text { 1. Pengertian } \\
\text { Arsitektur } \\
\text { Ekologis }\end{array}$ \\
\hline & $\begin{array}{l}\text { 2. Unsur } \\
\text { Arsitektur } \\
\text { Ekologis }\end{array}$ \\
\hline & $\begin{array}{l}\text { 3. Penerapan } \\
\text { Arsitektur } \\
\text { Ekologis } \\
\text { dalam } \\
\text { Perancangan }\end{array}$ \\
\hline
\end{tabular}

2. Informasi

Informasi dikumpulkan melalui buku - buku referensi dan situs situs internet yang berkaitan dengan penelitian. Informasi tersebut terdiri dari:

a. Peraturan daerah (RTRW) Kabupaten Lamongan;

b. Arsitektur Ekologis

C. Analisis

Tahap analisis merupakan tahapan yang bertujuan untuk mendapatkan kriteria kriteria dalam konsep wisata perikanan edukatif dengan pendekatan Arsitektur Ekologis yang akan dibuat.

D. Konsep Perancangan

Konsep perancangan berisi hasil analisa data yang telah dilakukan pada tahapan sebelumnya dan akan menjadi acuan dalam tahapan perancangan selanjutnya.

\section{ANALISIS}

\subsection{Analisis Pelaku dan Kegiatan}

1. Analisis pelaku kegiatan

Pelaku kegiatan terdiri dari: Pengelola dan pengunjung wisata perikanan. Jumlah pengunjung yang mengunjungi Wisata Perikanan Edukatif di Tanjung Kodok yang akan dirancang adalah sebanyak 2.781 jiwa per hari.

2. Analisis Kegiatan

a. Kegiatan pengelola 
b. Kegiatan rekreasi edukasi pasif

c. Kegiatan rekreasi edukasi interaktif

d. Kegiatan rekreasi edukasi partisipatif

e. Kegiatan penunjang rekreasi

\subsection{Analisis Kebutuhan dan Besaran Ruang}

Kebutuhan dan besaran ruang dalam wisata perikanan edukatif yang akan dirancang berdasarkan fungsi kegiatan pengelola dan kegiatan pengunjung adalah sebagai berikut:

Tabel 3. Kebutuhan dan Besaran Ruang

\begin{tabular}{|l|l|}
\hline \multicolumn{1}{|c|}{$\begin{array}{c}\text { Kebutuhan } \\
\text { Ruang }\end{array}$} & \multicolumn{1}{c|}{$\begin{array}{c}\text { Besaran } \\
\text { Ruang }\end{array}$} \\
\hline Penerima & $7.607,5 \mathrm{~m}^{2}$ \\
\hline Kegiatan Pasif & $1.508 \mathrm{~m}^{2}$ \\
\hline Kegiatan Interaktif & $1.337,9 \mathrm{~m}^{2}$ \\
\hline $\begin{array}{l}\text { Kegiatan } \\
\text { Partisipatif }\end{array}$ & $1.887,4 \mathrm{~m}^{2}$ \\
\hline $\begin{array}{l}\text { Kegiatan } \\
\text { Penunjang }\end{array}$ & $3.263,44 \mathrm{~m}^{2}$ \\
\hline $\begin{array}{l}\text { Kegiatan } \\
\text { Pengelola }\end{array}$ & $2.071,55 \mathrm{~m}^{2}$ \\
\hline
\end{tabular}

\subsection{Analisis Tapak}

\subsubsection{Analisis Lokasi}

Lokasi tapak berada di Jl. Tuban Lamongan, Kecamatan Paciran, Kabupaten Lamongan, Jawa Timur. Tapak memiliki luas $49.221 \mathrm{~m}^{2}$.

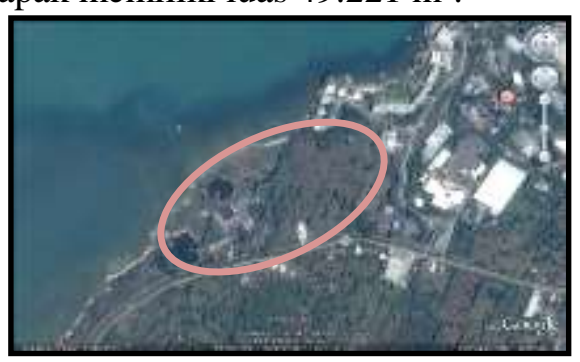

Gambar 1. Lokasi Tapak

Sumber: google earth

Batas tapak :

Utara : Laut Jawa

Selatan: J1. Tuban - Lamongan, Pemukiman, dan Maharani Zoo

Timur : Tanjung Kodok Resort, Wisata Bahari Lamongan

Barat : Lahan masyarakat.

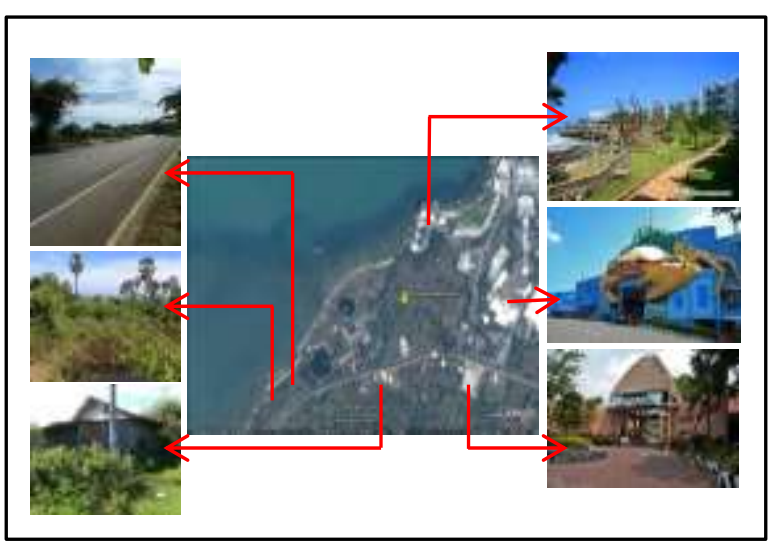

Gambar 2. Batas Tapak Wisata Perikanan

\subsubsection{Analisis Pemintakatan}

Analisis pemintakatan berdasarkan proses analisis kegiatan pelaku. Tapak dibagi menjadi empat mintakat antara lain:
a. Kegiatan Pengelola
b. Kegiatan Pasif
c. Kegiatan Interaktif
d. Kegiatan Partisipatif

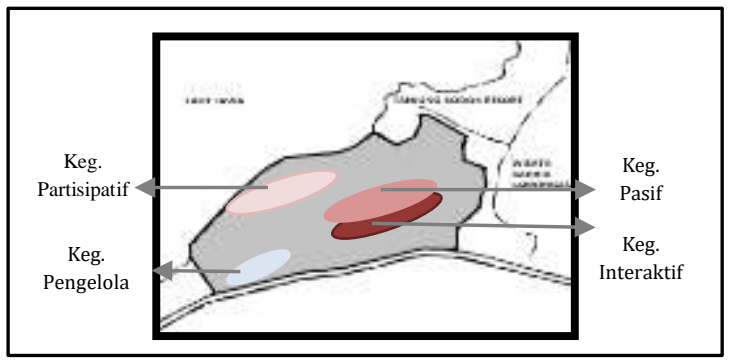

Gambar 3. Pemintakatan Kegiatan dalam Tapak

\subsubsection{Analisis Massa Bangunan}

Massa bangunan wisata perikanan edukatif dibagi menjadi lima massa yaitu:
a. Massa Utama;
b. Massa Kantor Pengelola;
c. Massa Penginapan;
d. Massa Restoran;
e. Massa Transit Wisata Nelayan.

\subsubsection{Analisis Orientasi dan Pemandangan}

Orientasi bangunan menghadap ke arah utara atau selatan (menghadap ke arah jalan utama). Pemandangan terbaik dari dalam tapak ke luar tapak diperoleh dari arah Laut Jawa yang terletak sebelah barat laut tapak. 


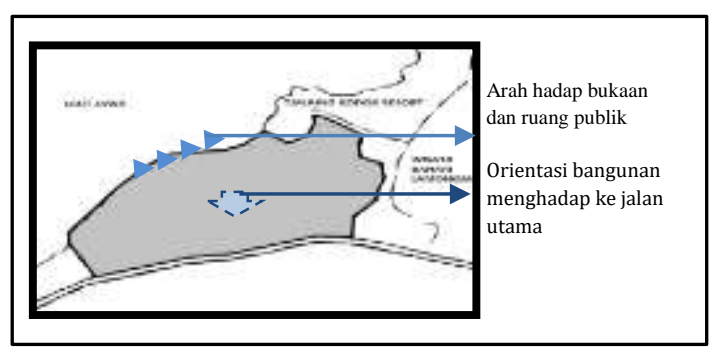

Gambar 4. Orientasi dan Pemandangan dari dalam Tapak

\subsubsection{Analisis Pencapaian}

a. Pencapaian Utama

Pencapaian utama diletakkan pada bagian tengah tapak, sedangkan pencapaian menuju kantor pengelola diletakkan pada bagian barat tapak.

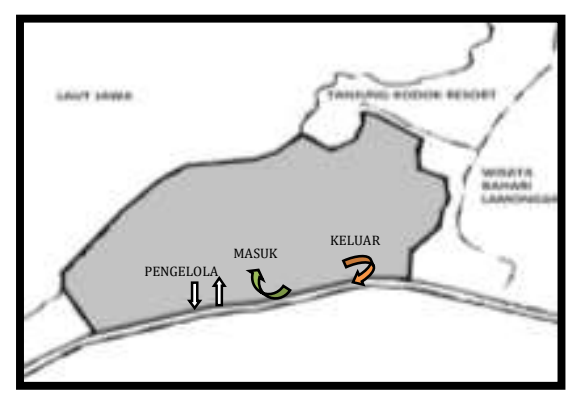

Gambar 5. Pencapaian Utama dalam Tapak

b. Sirkulasi dalam Tapak

Sirkulasi dalam tapak dibagi menjadi dua yaitu: Sirkulasi utama menuju area drop off dan sirkulasi yang menghubungkan antar massa bangunan. Sirkulasi utama menuju area drop off menggunakan ramp karena mengingat kegiatan pada massa utama terletak di lantai dua. Sirkulasi yang menghubungkan antar massa bangunan seperti massa utama menuju massa restoran, penginapan, massa transit wisata nelayan dan area tambak menggunakan jalan setapak yang dilengkapi dengan pergola tanaman rambat.

\subsubsection{Analisis Respon Klimatologis}

Kondisi klimatologis dalam tapak yang perlu direspon adalah panas matahari dan angin. Respon terhadap panas matahari adalah dengan cara mengahadapkan massa bangunan ke arah utara atau selatan, sedangkan bukaan yang menghadap ke arah orientasi matahari akan menggunakan sun screen untuk menghalau masuknya panas matahari tersebut. Respon terhadap hembusan angin yang berasal dari laut adalah dengan cara meletakkan vegetasi penahan angin di sebelah barat daya tapak.

\subsubsection{Analisis Lansekap}

Penataan lansekap dalam tapak ditunjang oleh dua elemen yaitu: Elemen vegetasi dan elemen air.

1. Elemen Vegetasi

a. Vegetasi yang berperan sebagai penahan panas matahari dan angin diletakkan pada bagian barat dan belakang tapak. Jenis vegetasi peneduh pada area publik yang digunakan adalah pohon ketapang dan pohon eksisting berupa pohon kelapa.

b. Vegetasi peneduh diletakkan pada area publik yang berdekatan dengan area kegiatan partisipatif. Jenis vegetasi yang digunakan adalah pohon flamboyan.

c. Vegetasi peneduh pada jalur sirkulasi diletakkan pada area parkir dan jalur antara area parkir dengan bangunan utama dan antara bangunan utama dengan bangunan - bangunan penunjang lain seperti penginapan dan restoran. Jenis vegetasi peneduh jalur sirkulasi menggunakan tanaman bugenvil.

d. Vegetasi untuk penutup tanah diletakkan pada area terbuka. Vegetasi penutup tanah pada area terbuka menggunakan rumput gajah mini.

e. Vegetasi untuk konservasi pantai diletakkan pada area yang berbatasan dengan pantai di sebelah barat. Vegetasi untuk konservasi pantai menggunakan tanaman bakau (mangrove).

2. Elemen Air 
Penataan elemen air dalam site dapat menjadi pendingin alami dalam tapak. Media air digunakan untuk mengkondisikan udara secara alami karena air dapat mendinginkan udara dan juga menenangkan angin yang berhembus (Sue Roaf: 2007)

a. Kolam air mancur diletakkan diantara area penerima dan disekitar massa utama;

b. Kolam penamung air hujan yang diletakkan menyebar pada bagian depan, tengah maupun belakang tapak;

c. Kolam penyaringan air (kolam filterisasi) diletakkan di depan massa utama;

d. Tambak ikan diletakkan memenuhi bagian belakang tapak.

\subsection{Analisis Fisik Bangunan}

\subsubsection{Bentuk Massa}

Massa bangunan menggunakan bentuk geometris karena karakternya yang mudah terukur sehingga mudah dalam pengaplikasian. Bentuk lingkaran digunakan pada massa utama sehingga dapat memberikan kesan bahwa massa utama tersebut merupakan bagian inti dalam wisata perikanan yang akan dirancang. Massa - massa penunjang menggunakan perpaduan bentuk lengkung atau lingkaran dengan persegi sehingga dapat menimbulkan kesan bahwa massa penunjang tersebut masih merupakan bagian dari massa utama (massa inti).

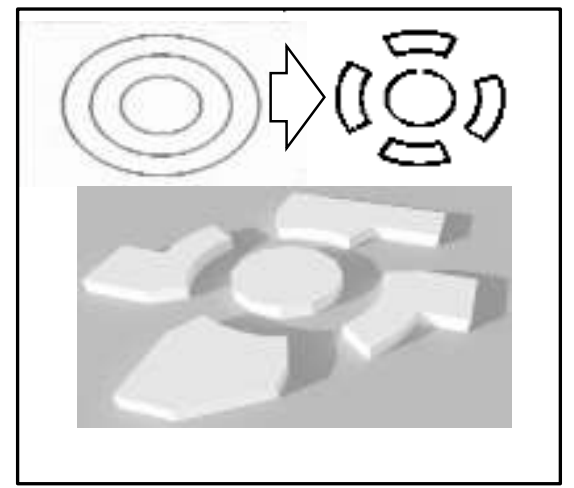

Gambar 6. Gubahan Massa

3.4.2 Tampilan
Tampilan bangunan dipengaruhi oleh penataan bukaan dan juga sun screen yang diaplikasikan pada tiap bangunan. Bukaan berupa jendela kaca diletakkan pada bagian utara dan selatan bangunan. Sun screen diaplikasikan untuk mengurangi efek silau dari dalam bangunan. Tanaman rambat digunakan dalam pengaplikasian sun screen pada tiap bangunan.

\subsubsection{Pemilihan Material}

Material bangunan menggunakan material yang dapat memenuhi syarat untuk bangunan bertingkat, selain itu material yang dipilih juga menggunakan material yang ramah lingkungan atau menggunakan material bekas pembangunan (recycle). Hal ini bertujuan untuk mengurangi pencemaran lingkungan. Pengaplikasian material ramah lingkungan yang sesuai dengan kriteria pemilihan material sebelumnya antara lain:

a. Material struktur menggunakan konstruksi beton. Konstruksi beton memiliki kekokohan untuk membangun massa utama berlantai dua yang berfungsi sebagai ruang ruang kegiatan wisata dan juga ruang pengelolaan ikan koleksi. Beton yang digunakan memakai bahan campuran fly ash sebagai pengganti semen yang banyak berasal dari daerah Jawa Timur. Penggunaan bacteria based self healing concrete dapat memperbaiki kualitas beton tersebut sendiri sehingga tidak memakan banyak waktu, energi dan biaya dalam hal perawatannya.

b. Material bukaan di dalam bangunan menggunakan limbah kaca. Limbah kaca digunakan untuk material bukaan di dalam bangunan karena selain untuk memanfaatkan limbah juga untuk menambah estetika dalam interior ruangan yang ditimbulkan dari gabungan pecahan limbah kaca.

c. Material langit - langit atau plester dinding menggunakan phosphogypsum. Material ini ramah lingkungan karena memanfaatkan limbah industri phosphiric acid yang ada di Gresik, Jawa Timur.

\subsection{Interior}


Aspek interior juga memerlukan perhatian sehingga dapat memberikan rasa kenyamanan dalam segi visual dalam bangunan bagi pengguna. Elemen dekoratif yang digunakan dalam interior bangunan dapat berfungsi mengatur kondisi udara dalam ruangan sehingga dapat meminimalkan penggunaan energi untuk membuat pengkondisian udara secara buatan. Elemen dekoratif yang dapat digunakan dalam interior antara lain:

a. Vertical garden merupakan salah satu elemen dekoratif yang dapat memberikan kenyamanan dari segi kualitas udara dalam suatu ruangan. Hal ini dikarenakan tanaman yang ditanam dapat mengeluarkan oksigen (proses fotosintesis) pada siang hari sehingga menghasilkan kualitas udara yang baik dalam ruangan tersebut. Media tanam vertical garden yang digunakan adalah media tekstil atau geotekstil. Menurut asbindo.org media tanam tekstil ini lebih mudah diaplikasikan, mudah perawatan dan juga biayanya relatif lebih murah bila dibandingkan dengan media tanam lainnya seperti VGM (vertical garden module).

b. Air terjun permanen dapat digunakan sebagai elemen dekoratif dalam ruangan. Selain sebagai elemen dekoratif, air terjun permanen juga dapat memberikan kesan sejuk dalam ruangan karena uap air dapat terbawa oleh udara yang bergerak dalam ruangan tersebut.

\subsection{Analisis Struktur dan Utilitas}

\subsubsection{Analisis struktur}

Struktur sebagai penopang bangunan memiliki peran yang sangat penting, oleh karena itu pemilihan jenis struktur yang sesuai dengan kondisi tapak dan bangunan perlu dilakukan. Struktur bangunan yang digunakan dalam wisata perikanan adalah sebagai berikut:

a. Sub structure (pondasi)

Tapak memiliki kondisi tanah yang labil sehingga konstruksi pondasi sepatu digunakan untuk mengkokohkan bangunan. Pondasi sepatu atau telapak juga kuat menahan beban bangunan yang direncanakan terdiri dari dua atau tiga lantai.

b. Supper structure (dinding)

Bangunan yang akan dirancang menggunakan struktur rangka yaitu penyalur beban berupa kolom dan juga balok dengan material beton dan baja. Perletakan kolom juga dapat diletakkan tepat di dalam dinding atau di luar dinding sehingga bentuk bangunan dapat lebih luwes.

c. Upper structure (atap)

Struktur atap menggunakan struktur beton dengan media tanam untuk pengaplikasian atap bertamanan.

\subsubsection{Analisis Utilitas}

a. Pencahayaan

Pencahayaan dibagi menjadi dua yaitu pencahayaan alami dan pencahayaan buatan.

1) Pencahayaan alami dalam rancangan terdiri dari:

a) Bukaan untuk pencahayaan alami maksimal terletak di ruang hall dan juga ruang ruang publik seperti restoran.

b) Skylight diletakkan di atas area akuarium dan area ke luar auditorium pada massa utama untuk menerangi vertical garden yang terdapat di bawahnya.

c) Bukaan yang menghadap ke arah barat atau timur menggunakan pengaplikasian sun screen.

2) Pencahayaan buatan dalam rancangan terdiri dari:

a) Ruang budidaya ikan dan air laut menggunakan jenis penerangan indirect lamp,

b) Ruang - ruang pamer menggunakan jenis penerangan direct lamp dan down light,

c) Ruang - ruang seperti auditorium, perpustakaan, dan yang lainnya menggunakan jenis penerangan direct lamp,

d) Area sirkulasi menggunakan jenis penerangan jalan yang diaplikasikan dengan panel 
surya tunggal dan juga menggunakan lampu taman.

b. Penghawaan

Pengahawaan dalam wisata perikanan edukatif dengan pendekatan Arsitektur Ekologis yang akan dirancang ini dibagi menjadi dua yaitu penghawaan alami dan juga penghawaan buatan.

1). Penghawaan alami yang akan digunakan antara lain:

a) Bukaan untuk penghawaan alami diaplikasikan pada ruang - ruang fungsi pengelolaan dan juga ruang publik seperti hall penerima,

b) Bukaan diletakkan pada bagian atas dan juga pada bagian bawah dinding berupa bouvenlight.

2). Penghawaan buatan yang akan digunakan antara lain:

a) Penghawaan buatan pada ruang pamer, auditorium, teater air, cinema menggunakan sistem AC sentral,

b) Penghawaan buatan pada ruang pengelola menggunakan AC split.

c. Energi Listrik

Energi listrik yang digunakan dalam wisata perikanan yang akan dirancang menggunakan energi listrik dari PLN dan juga energi yang dihasilkan dari panel surya.

d. Penyediaan Air Bersih

Air bersih yang digunakan dalam wisata perikanan edukatif dengan pendekatan Arsitektur Ekologis yang akan dirancang menggunakan air hujan yang dikumpulkan dalam kolam penampung air hujan dan juga menggunakan penyulingan air laut.

e. Sistem Sanitasi Air Kotor

Sistem sanitasi yang perlu diperhatikan dalam perancangan dibagi menjadi empat yaitu sistem sanitasi air hujan, sistem sanitasi black water, sistem sanitasi grey water, sistem sanitasi air limbah akuarium.

1) Sistem sanitasi air hujan
Air hujan dialirkan melalui saluran drainase menuju kolam penampung air hujan yang selanjutnya akan disaring dalam tangki penyaringan dan dapat digunakan untuk kebutuhan servis dalam bangunan.

2) Sistem sanitasi black water Limbah WC akan dialirkan menuju biotank yang kemudian akan disalurkan menuju roil kota.

3) Sistem sanitasi grey water

Grey water dapat dimanfaatkan kembali untuk kebutuhan penyiraman tanaman setelah melalui bak penampung lemak dan tangki pengolahan terlebih dahulu.

4) Sistem sanitasi air limbah akuarium

Air limbah akuarium dialirkan menuju tangki penyaringan kemudian masuk tangki pengolahan. Air limbah yang telah diolah tersebut selanjutnya dapat dengan aman dibuang ke laut.

\section{KESIMPULAN}

Permasalahan dalam Wisata Perikanan Edukatif di Tanjung Kodok yang akan dirancang adalah bagaimana merancang tempat wisata perikanan edukatif di Tanjung Kodok dengan pendekatan Arsitektur Ekologis. Setelah melakukan beberapa analisis, maka hasil rancangan yang menggunakan pendekatan Arsitektur Ekologis antara lain:

\section{A. Rencana Tapak}

Rencana tapak merupakan hasil dari analisis kegiatan dan kebutuhan ruang, analisis tapak, analisis lansekap, dan analisis struktur utilitas.

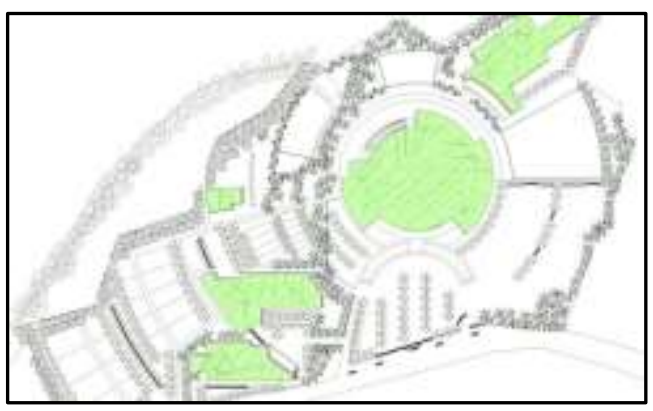

Gambar 7. Rencana Tapak 
B. Tampak Bangunan

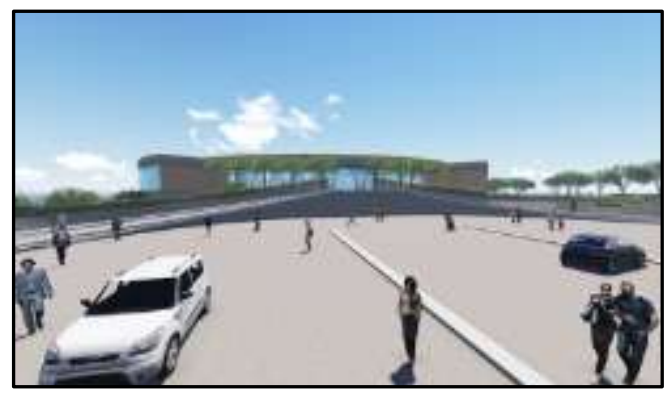

Gambar 8. Tampak Massa Utama

Tampak utara massa utama memperlihatkan sun screen tanaman rambat dan bukaan - bukaan berupa jendela mozaik. Selain itu tampak utara massa utama tersebut juga memperlihatkan ramp untuk mengakses massa utama.

C. Perspektif Interior

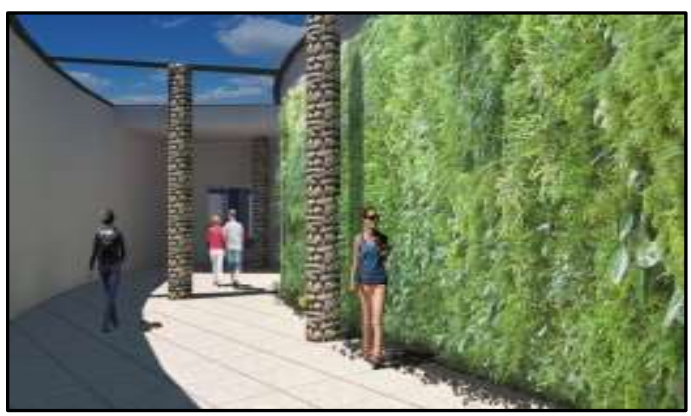

Gambar 9. Perspektif Interior

Elemen dekoratif berupa vertical garden diletakkan pada koridor antar ruang. Penyinaran vertical garden tersebut diperoleh dari skylight yang terletak di atasnya.

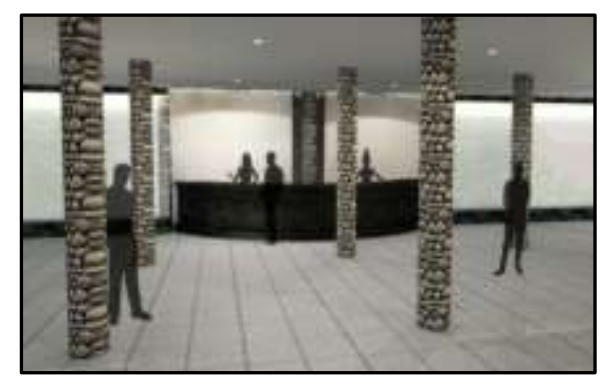

Gambar 10. Perspektif Interior Hall
Elemen dekoratif berupa air terjun permanen diletakkan di hall. Elemen air tersebut dapat menjadi penghawaan alami dalam ruang sehingga dapat memberikan kenyamanan bagi pengunjung.

\section{REFERENSI}

Frick, Heinz \& Suskiyatno, Fx. Bambang. 1998. Dasar - Dasar Eko-Arsitektur.

hosyatillah, 2009. "Analisis Kepuasan Konsumen Terhadap Mutu Pelayanan Pengelola Wisata Bahari Lamongan". Bogor.

Sue Roaf, Manuel Fuentes and Stephanie Thomas. 2007. Ecohouse: A Design Guide. Elsevier Ltd. 